\title{
Hackers of Port-Royal : various philosophers and mathematicians of that institution.
}

\author{
Camille Akmut
}

May 22, 2020

\begin{abstract}
Introduction

Even historians writing at the beginning of the 20th c. felt the need to apologize to their readership for writing "yet another history" of Port-Royal ${ }^{1}$.

But, this is guaranteed not one of them!;

Were the Port-Royal intellectuals history's first "hacker" group? - we ask here.

They mixed various disciplines, attitudes towards knowledge (from degreeholding like Arnauld to self-taught like Lancelot or home-schooled like Pascal), and specialties (pedagogy to epistemology); forming an ensemble of personalities whose success lied somewhere between anarchism of methods, if not ideas, and communism of resources; practices that recall today's hackers - no anachronism intended this time.

At the very least they offer an example of how to create an interdisciplinary collective in the 17th century (covering philosophy, linguistics, mathematicsengineering, etc.)... History for history's sake is futile, and present-day readers may derive their own lessons from these now partially forgotten figures.

The linguist Jean-Claude Pariente noted, apologizing too, that it was not always easy to distinguish between "logic and grammar", and this was no banality to acknowledge;

For the historian the main difficulty lies in making choices :

between the Trojan horse of classical literature - an early recorded instance of social engineering - and that of Headley, we must draw lines somewhere too. They should be neither too large, nor narrow.
\end{abstract}

\footnotetext{
${ }^{1}$ Bremond made this remark in his 'History of religious sentiment', who explicitly meant Sainte-Beuve [but these histories go back to the 17th c., and Racine can be named a.o..]
} 


\section{NOT EVERYONE HAS THE SAME SKILLSET}

Or, the same level of skills;

Pascal had a unique knowledge of computers (in fact, Pascal, it could be argued, was the world's expert on that question - Schickard excepted), and had more knowledge of mathematics than anyone else in that group (at least Arnauld).

"Pascal had by far the greater knowledge of mathematics, as Arnauld freely confesses" - The Mathematics of Great Amateurs, p. 105.

Nicole had historical skills :

"a historian well versed in the theological systems of the past, he could discern the complexities of issues that the naivety and ignorance of [others] handled without problems (...) To that group ["parti"] he brought a spirit already fashioned elsewhere, habits, methods and intellectual preferences"2

("at the age of fourteen [had] read all the Greek and Latin authors in his father's library"3)

\section{NO ONE IS DUALIFIED, OR AUTHORIZED}

Arnauld had aspirations in law and later advanced degrees in theology (an expert of the Church fathers - e.g. St Jerome or Augustine).

Pascal had no degrees, was home-schooled by a father mathematician.

Nicole was a historian. Lancelot seemed more preoccupied with pedagogy (being in charge of schooling?)

$\mathrm{P}$. was not received in P-R with a warm welcome,

"Coming from a person such as him, No miracle can be expected" Mother Angelique judged ${ }^{4}$,

while it took a long time for Nicole to join the group, never quite accepted.

"He [Nicole] was regarded with some suspicion : he was accused of

"spoiling the spirit of Arnauld"",

Then the miracle came in the form of not only the Pensees, a work written by a former mathematician and engineer that handled in addition to number theory and machines, of tides and the moon, Justice and Man's nature; but also

\footnotetext{
${ }^{2}$ Strowski $1908: 7$

${ }^{3}$ Tollemache $1893: 163-4$.

${ }^{4}$ Found in Strowski 1908 : 8. [Vol. 3]

${ }^{5}$ On Nicole's beginnings at P-R : Strowski 1908 : c. 6-7.
} 
in form of an influential Grammar and a Logic - precursors of Chomsky (at least according to $\mathrm{him}^{6}$ ).

Who had given Pascal an authorization to declare himself a philosopher? No one. [Just as no one had given McCarthy any permissions to work on Lisp.]

Lancelot, co-author with Arnauld of the Port-Royal Grammar, seems to have been mostly self-taught.

"As Lancelot advanced in years, he was conscious of grave defects in the system [of the seminaries where he had been put] there was but little spiritual training, (...) He acquired a certain amount of Greek and Latin and Theology, sufficient"

for his purposes... [then met S-C, etc.]

\section{EXCHANGES OF IDEAS}

To give one example of this, Arnauld's 'New elements of geometry', a textbook aiming to reform the teaching of that discipline, can be named which came as the result of an improvement made upon Pascal's own work :

"He tells us in the preface [the] story of how he came to write it. Pascal (...) had written a short essay on the beginnings of geometry. This fell into the hands of Arnauld, who was astonished at the confusion that subsisted in the work owing to the unnaturalness of the order. He said jokingly that if he had a little time, he could produce something much better. The occasion arose, and he produced the book under discussion."

— ibid, $108^{8}$

Pascal recognized it as such and welcomed the changes, according to Nicole ${ }^{9}$

"When Pascal saw that work he [discarded his own] and admitted frankly that M. Arnauld's work [was better]"

Nicole is also reported to have held that (compatible with the above) :

"The mind is formed more by intercourse with others than by anything else. What one reads one forgets; it is only when one has said a thing that one really knows it" (trans. Marguerite Tollemache?) ${ }^{10}$

\footnotetext{
${ }^{6}$ For a critique of this illustrious attributed heritage, see Pariente 1975.

${ }^{7}$ Tollemache $1893: 28$.

8 (Coolige himself based his developments on (historian of maths) Bopp.)

${ }^{9}$ Cited in Coolidge, here a translation is provided.

${ }^{10}$ Tollemache's monograph, the section on Pierre Nicole.
} 


\section{DATA NETWORKS}

Mersenne received, read, sent, and communicated back thousands upon thousands of messages...

Descartes continued to write to him until shortly before his death; Arnauld in turn sent-got from Descartes two letters in the year 1648 (D. died in 1650).

\section{SOME UNITY IS REQUIRED, BUT NOT EVERYTHING MUST BE SHARED}

Port-Royal philosophers's common ground was the union of Augustine (through Jansen and St-Cyran) and Descartes.

They agreed on religion, and specifically Jansenism, as well as a general direction for philosophy (with some disagreements here).

If Pascal was going to choose Christianity, he would also pick (what he perceived to be) its most strict variant. He was uncompromising in that way.

Jansenism - based on a re-reading of Augustine - preferred ideas of sin, penitence and, perhaps even more stringently, predestination : the idea that it was not a matter of individual efforts, but God had already chosen.

This however did not mean that everyone needed to share all of the same ideas.

Pascal had famously attacked Descartes, but Arnauld and Nicole (and others) were close to Descartes ${ }^{11} \ldots$

D. in turn held Arnauld in highest esteem :

"It would have been hard to wish for a better judge of my writings, than the one whose remarks you have sent to me; he treats me with such gentleness and civility, that I can very well see that nothing in his aim was directed against me or the subjects which I study; and yet with great care he examined what he fought, that I am also certain [he has fully understood me]"

[background : the meditations were followed by so-called objections by prominent philosophers of the time, among whom Arnauld, Gassendi, Hobbes... Arnauld's objection was communicated to D. via Mersenne]

And, even Pascal had been obviously very influenced by Descartes : his writings on infinity echo those in particular of the 3rd meditation ('That there is a God'). God's attributes (Fifth meditation). Etc..

"By (the word) God I mean an infinite, eternal, immutable... substance."12 "Par le nom de Dieu j'entens vne fubftance..."

\footnotetext{
11 "They were the most famous, but not the only ones who united the love of Augustine with that of Descartes" (See the entire passages, pp. 432-4, in Bouiller 1865.)

12 Oeuvres $9: 35$.
} 
(whose publication had preceded Pascal's writings on that topic, Pensees, by about a decade or two, first in Latin)

We find in Descartes the same, or similar ideas about infinity being something that escapes human reason, all the while being a part of it :

"for, as much as the idea of this substance is within me (...) being finite myself, I would not have an idea of an infinite substance, had it not been placed there by some truly infinite substance"13

The same could be said of the Port-Royal Logic whose various parts recall some of the meditations e.g. the Fourth one "Of false and true".

\section{COMNON SPACES, RESOULCES}

"They have most likely put their resources in common (...) The administration of these resources are placed in trusted hands (...) they retain personal autonomy, and regulate their days according to their conscience"14

Port-Royal, being the headquarters of Jansenism, was the space where our hacker-philosophers gathered (with other like-minded individuals they stayed in contact through letters).

\section{LIBERATION FROM IMPOSED WORK}

In the 17 th c., (as in the 21 st...), a principal way to escape work - a condition to dedicate oneself to other, more important tasks - was to be born into the right families. Pascal and Arnauld both fit this pattern, coming from the same background of 'robe nobility', and Nicole too ${ }^{15}$.

Others, like Mersenne, came was from the people, and found in the religious professions spaces of freedom that allowed them to turn to their various activities. Lancelot "was placed in the seminary" when twelve years old ${ }^{16}$.

\section{DISCIPLINE}

"Every day they get up at three in the morning", "go to bed at eight". This gives them 7 hours of sleep. Still in bed, their work starts. Not fully clothed, their work continues... It never ends, and repeats itself. [See appendix]

\footnotetext{
${ }^{13}$ Oeuvres $9: 36$.

${ }^{14}$ Strowski $1908: 4$.

${ }^{15}$ The latter possibly to a lesser extent. His father is described in any case as "a ... lawyer, ... and a classical scholar, who rose to be a judge" (Tollemache).

${ }^{16}$ Tollemache $1893: 27$.
} 


\section{*** Epilogue}

Pascal died in 1662.

Port-Royal was repeatedly attacked (for "heresies" - the 17th c. equivalent of "terrorism", one concept as malleable as the other), and finally destroyed.

"Arnauld was in his sixty-eighth year when he [fled] (...). Nicole, always [slightly cowardly], had already taken flight, and made his way to Brussels, where he was afterwards joined by Arnauld. But Nicole soon deserted his old friend, and entered into correspondence with the Archbishop of Paris, promising him complete subservience if only he might be permitted to return (...) Arnauld kept to his purpose, and remained till his death..."17

${ }^{17}$ Tollemache $1893: 144$. 


\section{Primary sources}

* Arnauld.

- Objection to the Meditations.

- Les nouveaux elements de Geometrie.

* Arnauld and Lancelot.

- Grammaire.

* Descartes.

- Meditations...

e.g. Adam and Tannery vol. 9. [Older French], Beyssade [Modern French]. (The Meditations is a short text. Divided into 6 meditations.)

- Answer to Arnauld's objection (sent to Mersenne). e.g. Beyssade.

- (1647-1650). Correspondence with Arnauld, Mersenne... e.g. Adam and Tannery vol. 5. [part Latin]

Adam and Tannery (eds.). Oeuvres. Leopold Cerf. Many vol..

(The same Tannery was also responsible for an Oeuvres of Fermat.)

-. 1904. Vol. 9. -. 1903. Vol. 5.

Beyssade (eds.). 2011. Meditations metaphysiques. Flammarion.

(For 'objections' and D.'s answers.)

* Fontaine, Nicolas. 1738 [mdccxxxviii]. Memoires pour servir... / 'Memoirs to serve in the history of Port-Royal' by M. Fontaine. Vol. 1. Cologne.

\section{Secondary sources}

- Bouillier, Francisque. 1865; 68. Histoire de la philosophie cartesienne. Delagrave etc.. 2 vol..

- Coolidge, Julian. 2002 [1949]. The Mathematics of Great Amateurs. Oxford University Press.

- Pariente, Jean-Claude. 1975. "Grammaire generale et grammaire generative" Actes... 1(5-6) : 36-49.

("Arnauld et Nicole : precurseurs de Chomsky?")

-. 1984. "Grammaire et logique a Port-Royal" Histoire Epistemologie Langage $6(1): 57-75$.

- Tollemache, Marguerite. 1893. French Jansenists. Kegan etc..

((Early?) English-language book on Saint-Cyran, Pascal, Arnauld, Nicole...) 


\section{ACCOUNT \\ Of the conduct and exercises of the solitary penitents of Port-Royal des champs; November 23rd of 1644.}

Every day they ["ils"] get up at three in the morning, and so soon as awake, following the sign of the cross, go through the following adorations.

Act of adoration done in the morning upon waking up, while still lying in bed.

Blessed be the day of the birth, the death and the resurrection of JesusChrist.

Having put on a part of their clothes. Adoration to the Saint Trinity

Oh my God, Father, Son and Holy Spirit, I adore you - in your unity and the trinity of your persons. I thank you for having preserved me during the night and beg you to guide me through this day.

(...)

I make honorable amends for all the sins that I have committed from the time I was able to use reason up to now.

\section{Adoration to our Lord Jesus-Christ}

I adore you, oh my savior Jesus-Christ and your humanity [realized in all of your states], mystery, thoughts, speeches/words, actions, movements, pain interior and exterior. [repetition of previous adoration]

\section{Hail the Saints}

I salute you, oh Saint Michel, and you, my guardian Angel, S. Pierre, S. Paul, S. N. patron of this place, and you S. N. my patron. (...)

\section{Daily demands}

Give me grace, oh my God, to be among those few select ones who will be called to you.

[Note : reference to the theory of predestination, see Augustine, Jansen.]

(...)

Be graceful and let me live and die a penitent.

(...)

Following these acts of adoration, now properly clad, they taken holy water while saying "Afperges me".

$[\ldots]$ 


\section{THEIR PRAYERS}

Every day, they read one chapter of the Gospel and of S. Paul on their knees, as $\mathrm{S}$. Charles had, whose eminent saintliness was particularly venerable to them, for having in their own times restored penitence.

(...)

Thus God speaks to them in his holy Scripture, and they [to him/them] in their prayers. (...) They read these divine statements with a deep reverence; adoring those they do not hear ["qu'ils n'entendent pas"], as S. Augustine had ordered ... (...)

We go to bed at eight, after having done the above-reported adorations. Thus one sleeps from 8 to 3 , which gives seven hours.

\section{MANUAL WORKS}

Two hours in the morning and two hours in the afternoon ["apres-dinee"] are reserved for manual work. Trees are pruned. One works on plants or herbs. We pick fruits; and one only concentrates on necessary works.

(...)

They [the solitaries] keep happy, and feel honor from the humiliation/humility of these tasks.

(...)

after all S. Paul himself worked and ordered the Christians of his days to work [similarly]

\section{THEIR SATISFACTION AND JOY}

Grace have healed them from their most violent passions, their material desires, and the worldly honors ["defirs des bien \& des honeurs"] that put men in a position of servitude;

they only seek God which they find at every hour of the day.

(...)

\section{THEIR SOLITUDE}

They only deal with the [discoveries / "nouvelles"] of the other world (...) They have renounced all those of this one.

(...)

having only curiosity for the science of Saints, to learn to live in a good way, and to die; (...)

\section{THEIR ACCOMMODATION}


They are lodged in few infirmary rooms left [by the female religious] (...) sufficient for those who believe that Christian poverty and penitence must reign outside, as well as inside the heart.

\section{THEIR AUSTERITY}

(...) They sleep on [beds made up of] straw (...)

Memoires pour servir... Vol. 1. xciii ff. [93] 